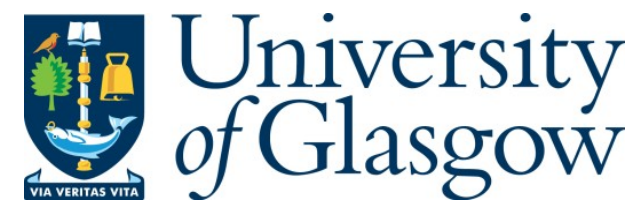

Featherstone, D. (2014) Black internationalism, international communism and anti-fascist political trajectories: African American volunteers in the Spanish Civil War. Twentieth-Century Communism: A Journal of International History, 7 . pp. 9-40. ISSN 1758-6437

Copyright @ 2014 Lawrence \& Wishart

http://eprints.gla.ac.uk/95688/

Deposited on: 05 November 2014

Enlighten - Research publications by members of the University of Glasgow http://eprints.gla.ac.uk 


\title{
Black internationalism, international communism and anti-fascist political trajectories: African American volunteers in the Spanish Civil War
}

\author{
David Featherstone
}

n his autobiography Black Bolshevik Harry Haywood writes of the importance to his political development of meeting Irish radicals at the University of the Toilers of the East in Moscow. Haywood, one of the leading African American figures in the Communist Party of the USA (CPUSA) in the inter-war period, was the author of influential texts such as Negro Liberation. He notes that:

The Irish students came from the back ground of the 1916 Easter Rebellion and the revolutionary movement reflected in the lives of men like Larkin and James Connolly. Among them were Sean Murray and James Larkin, Jr, (Big Jim's son). All of them had been active in the post-war independence and labor struggles. I was closest to Murray, the oldest of the group, who was a roommate of mine.

This was my first encounter with Irish revolutionaries and their experiences excited me. As members of oppressed nations, we had a lot in common. I was impressed by their idealism, and revolutionary ardor and their implacable hatred of Britain's imperialist rulers, as well as for their own traitors. But what impressed me most about them was their sense of national pride - not of the chauvinistic variety, but that of revolutionaries aware of the international importance of their independence struggle and the role of Irish workers. ${ }^{1}$ 
Haywood's account of his time in Moscow emphasises some of the forms of exchange, connection and political relation that were produced through communist political networks. Such relations unsettle the divisions between 'centre' and 'periphery' which have often structured ways of narrating communist internationalism and politics. Further, they emphasise that such connections could be productive. Haywood notes that 'through his association with Irish radicals in Moscow', he became 'deeply interested in the Irish question, seeing in it a number of parallels to US Blacks', arguing that this interest heightened his 'receptivity to the idea of a black nation in the United States'.

By 'black nation' Haywood refers to the argument that black people in the southern United States constituted an oppressed and colonised 'nation'. Haywood was a leading advocate of this position in the CPUSA. Known as the 'black belt nation thesis', it was one of number of policies and interventions through which the CPUSA built an important support base among African Americans during the 1930s. Haywood was also to become one of the most prominent African American communists to serve with the International Brigade during the Spanish Civil War. A firm proponent of stalinism and scourge of 'revisionism' within the CPUSA, together with another African American brigadist Admiral Kilpatrick, he was involved in the Provisional Organising Committee for a Communist Party that was founded in 1958 over disagreements with the CPUSA, and attracted 'mainly Black and Puerto Rican working class cadres'.2

This article considers some of the political trajectories of the ninety or so African Americans who fought in Spain with the Abraham Lincoln Battalion, the George Washington Battalion and the John Brown Battery that formed part of the Fifteenth International Brigade, 'along with British, Irish, Canadian and other nationals' ${ }^{3}$ It locates these trajectories as part of broader interventions made by black internationalist intellectuals and activists in shaping the terms on which anti-fascism was articulated. The first section engages with recent scholarship on black internationalism, drawing out the implications of such work for theorising the intersections of communist internationalism and the black left(s). The article then explores how relations between the CPUSA and African Americans shaped the context through which black volunteers

Twentieth Century Communism - Issue 7 
joined the Fifteenth International Brigade, and how they were subsequently shaped through their experiences of combat in Spain. The final section probes some of the limits to black internationalism through discussing how the colonial relations between Spain and Morocco exerted pressure on the formation of anti-imperial solidarities.

\section{Thinking the spatial politics of international communism}

Harry Haywood's presence in Moscow was part of a set of interconnections between anti-colonial and communist politics which are significant, and which forged generative if uneven, contested and at times troubling connections. Such geographies resonate with Sharad Chari and Katherine Verdery's call to bring together 'postsocialist and postcolonial studies toward rethinking socialist and anti-colonial values simultaneously. ${ }^{4}$ This agenda is significant for work on black internationalism as many key figures such as Paul Robeson, W.E.B. Du Bois, Langston Hughes and Louise Thompson spent significant periods of time in the USSR, and this had a transformative impact on their political beliefs and understandings. African American figures in the CPUSA who would be involved in the Spanish Civil War, such as Mack Coad, an activist with the Share Croppers Union in Alabama, also spent time at the University of Toilers of the East in Moscow in the 1920s and 30s. ${ }^{5}$

For Kate Baldwin such connections assert the importance of often marginalised 'transnational genealogies of black internationalism'. ${ }^{6}$ Haywood's discussion of the influence of Irish communists on his articulations of the 'black belt nation thesis' are but one example of the significance of such connections. While this position was always contentious, and subject to critique from various positions, the adoption of the black belt thesis by the CPUSA endowed the black struggle 'with unprecedented dignity and importance'. 7 This distinctive approach to racialised politics of the United States was in part influenced by Lenin's 'Thesis on the National and Colonial Question', which was presented at the Comintern's Second Congress in $1920 .^{8}$ As part of the preparations for the Comintern's Sixth World Congress, Haywood presented a paper arguing that AfroAmerican people had a distinct 'national minority status' to a sub-committee on the 'Negro Question'. ${ }^{9}$ This influenced the 
adoption by 1930 of 'self determination' in the 'black belt' as official CPUSA policy, until it was revoked by Earl Browder in 1943.

The genealogies of the 'black belt nation thesis', as Minkah Makalani has argued, however, lie in a set of exchanges and relations between black and Asian radicals which were largely forged outside of the 'white Left'. ${ }^{10}$ There were longstanding attempts by black radicals in the US to articulate the idea of a separate nation-state for black people, notably by Cyril Briggs of the African Blood Brotherhood (ABB), an organisation founded in 1919 as a 'systematic attempt to organically conjoin radical black nationalism with revolutionary socialism'. ${ }^{11}$ Briggs saw a black nation-state as 'essential to diasporic liberation', which would come 'out of the political movements of continental and New World Africans, though the two did not constitute a single struggle'. ${ }^{12}$ In the early 1920 s the CPUSA had recruited figures from the African Blood Brotherhood. The ABB had significant involvement of Caribbean immigrants such as George Padmore from Trinidad and Briggs from St Kitts, who played 'a key role in bringing other black people into the party, especially in the 1930s'.13 This reflected the importance of Caribbean immigrants in shaping radical black movements in the US in the early twentieth century, despite occasional hostile reception to Caribbean radicals from established African American political figures. ${ }^{14}$

These currents intersected with challenges to the terms of Lenin's articulation of nationalism and anti-colonialism. Thus M.N. Roy critiqued Lenin's 'Thesis on the National and Colonial Question' and drafted, at Lenin's request, a 'supplementary set of theses', which he submitted to the National and Colonial Commission; these positioned South Asia and the global South 'at the nexus of proletarian revolution'. ${ }^{15}$ This analysis was based on a strong critique of the forms of internationalism envisioned by the Second International. Thus Roy argued that

the Third International is a fighting body which must assume the task of combining the revolutionary forces of all the countries of the world. Dominated as it was by a group of politicians permeated with bourgeois culture, the Second International failed to appreciate the importance of the colonial question. For them the world did not exist outside of Europe'. ${ }^{16}$

Twentieth Century Communism - Issue 7 
Interventions by Asian radicals such as Roy opened up the Comintern 'so that it might be seen as a vehicle for pan-African liberation'. ${ }^{17}$ The diverse geographies of connection and solidarity they constituted challenge nation-centred accounts of African American politics and of US Communism. Accordingly Brent Hayes Edwards has positioned the 'New Negro' movement as part of the 'transnational contours of black expression'. He contends that:

To note that the 'New Negro' movement is at the same time a 'new' black internationalism is to move against the grain of much of the scholarship on African American culture in the 1920s, which has tended to emphasize US-bound themes of cultural nationalism, civil rights protest, and uplift in the literary culture of the 'Harlem Renaissance'. ${ }^{18}$

Edwards argues for the importance of 'tracking the transnational contours of black expression between the world wars', and 'accounting for the ways that expression was moulded through attempts to appropriate and transform the discourses of internationalism that seemed to centre "the destinies of mankind", as Du Bois put it in 1919'. This positions black internationalism as a set of contested and multiple interventions.

Edwards's work resonates with attempts to move beyond periphery/ centre models of the spatialities of international communism and to de-centre the national in accounts of left histories. ${ }^{19}$ His account is notable not just in terms of the way he insists on problematising nation-centred accounts of the cultural and political. It is significant in foregrounding the multiple and differentiated political and cultural practices constituted through black internationalist politics. $\mathrm{He}$ foregrounds diverse networked forms of political activity formed through various black internationalisms in the 1920s and 30s. These include, but are not limited to, elitist forms of internationalism associated with notions of the Talented Tenth or the 'vagabond internationalism' depicted in Claude McKay's novel Banjo. ${ }^{20}$ Edwards's work foregrounds the diverse geographies and social relations forged through black internationalist practices. He demonstrates that there 
are both important histories and geographies and heterogeneous social relations constituted through such practices.

This project is significant in foregrounding diverse forms of political trajectories and agency constituted in relation to practices of communist internationalism. It relates to work which has challenged the association of transnationalism and cosmopolitanism with elite practices. ${ }^{21}$ As Glick Schiller argues, it is necessary to problematise this association of cosmopolitanism with elitism. She argues that there is vital work to be done to theorise, learn from, and note the differences between current social movements and sensibilities and eighteenth, nineteenth century and early twentieth century transnational social movements and their cosmopolitan perspectives, including various forms of internationalism displayed by labour, Pan-Africanism, anticolonialism and feminism'.22 Such exchanges and articulations of internationalism continue to be marginalised in histories of the left, which are based on rather nationcentred accounts of internationalist practices. ${ }^{23}$

Glick Schiller's injunction to learn from the diverse traditions that have mobilised and shaped internationalism in the past is instructive. The importance of these different theoretical and political traditions for thinking about the relations between internationalism, space and politics, however, has been neglected in both geography and the broader social sciences. Thus work on black internationalism has signalled the importance of such alliances and flows to place-based political activity, and has evoked the important imaginative geographies of politics and resistance generated by key political activists and intellectuals such as the radical pan-Africanists C.L.R.. James and George Padmore, both from Trinidad, and Paulette Nardal, the Paris-based Martinican editor, translator and author, associated with the Negritude movement. This permits a focus on the differentiated and contested geographies that constitute internationalist political activity. Such a move is essential for developing accounts that are alive to the multiple geographies that constituted, and were constituted through, communist internationalism.

Edwards's account of black internationalisms in the 1920s and 1930s uses such an approach to foreground the productive geographies of connection that shaped relations between communist internationalism and anti-colonialism. His discussion of the collaboration in the 1930s

Twentieth Century Communism - Issue 7 
between George Padmore and Tiemoko Garan Kouyaté is particularly apposite here. George Padmore was organiser of the International Trade Union Committee of Negro Workers sponsored by the Comintern, and was the founding editor of its paper, the Negro Worker. Padmore broke with the Comintern over the subordination of anti-colonial work to the geo-political interests of the USSR, and became a key figure in panAfrican politics. ${ }^{24}$ Kouyaté, from the French Sudan, led the Paris based anti-colonial group Ligue de Défense de la Race Nègre, editing its paper Le Cri Des Nègres. ${ }^{25}$ They met at the second congress of the League Against Imperialism in Frankfurt in July 1929, and collaborated through Comintern-sponsored anti-colonial work. ${ }^{26}$

Accounts of their collaborative work emphasise the importance of engaging with geographies of connection that exceed relations between national left politics and internationalism. Thus Makalani notes that, early in 1931, 'Padmore arranged for Kouyaté to organise black maritime workers in Marseilles for the International of Seamen and Harbour Workers'. Despite notable successes, however, 'the PCF continued to neglect colonial work and gave no support to Kouyaté, and Padmore used his position in the Comintern to urge the PCF to provide Kouyaté with better support, and to integrate 'black [nègres] dockers and sailors of French ports into revolutionary unions' ${ }^{27}$ Edwards uses a discussion of the dynamics of this collaboration to stretch the terms of nationcentred accounts of the spatial politics of communist internationalism. Thus he argues that:

There are at least two versions of black internationalism here. The Padmore- Kouyaté collaboration is on one hand a function of the Comintern policy envisioning an 'international trade union' approach to black labor. But their circumventing of the French national party points toward another internationalism as well, one not wholly subsumed in a Comintern agenda, one that emphasizes race-based organizing and anticolonial alliances among differently positioned revolutionaries of African descent. ${ }^{28}$

This account stresses the multiple geographies through which forms of black internationalist practice were constituted. It unsettles accounts of 
internationalism which focus more or less exclusively on inter-relations between the national and international. Edwards also moves discussion on from situating anti-colonial politics as something which was straightforwardly marginalised through the organisational geographies of the left. Rather, different articulations of internationalism are produced here, both through refusing the chauvinist forms of nationalisms generated through the French communist party, and through invoking and mobilising relations with the Comintern.

Padmore and Kouyaté, however, also refused to be neatly circumscribed within the agenda of the Comintern. As Makalani argues, the interventions of such anti-colonial radicals could 'stretch' the political theorisations associated with communist internationalism. One key intervention here was the way that figures such as George Padmore and Langston Hughes located discourses of anti-fascism in relation to struggles against colonialism and racism. These discourses challenged what Paul Gilroy has described as a tendency to circumscribe understandings of fascism, and anti-fascism, within bounded European contexts. ${ }^{29}$ Thus Hughes and Padmore linked the conflict in Spain to the struggles and global organising against Italy's invasion of Ethiopia. The originality and importance of their analysis of fascism and anti-fascism emerge by comparison with contemporaneous writings on fascism by the Italian communist leader Palmiro Togliatti.

Togliatti reflected in depth on the character of Italian fascism in a set of lectures given to Italian comrades at the Italian division of the Lenin School in 1935. The lectures formed the bulk of a fifteen-part course on 'The Adversaries' facing Italian communists. Togliatti's lectures deal with diverse facets of fascism and draw out significant theoretical and political challenges in opposing and analysing Italian fascism. While his analysis is rooted in a 'class analysis', his account also addresses some of the challenges of the socially heterogeneous nature of the support for fascism. He also acknowledges some of the mistakes of the Italian communist party in failing to counter the rise of Italian fascism and to adequately understand it. He writes that: 'At bottom, membership in the Fascist Party represents a bond - a more or less ideological bond'. He continues that such bonds can be cut only with 'tenacious work by our Party':

Twentieth Century Communism - Issue 7 
It is an error to think that these bonds will break by themselves. Some of the resistance we run up against in our work at the factories is due, perhaps, to the fact that we do not always understand how this bond must be cut. ${ }^{30}$

Further, he notes that:

Every time the Communist Party is able to find a crack, a fissure in fascism, it must drive a wedge into it, in order to render the situation mobile again and thus reopen the possibilities of struggle. ${ }^{31}$

While Togliatti does not completely ignore the colonial contexts of Italian fascism, he doesn't address the implications of this context for either analysing fascism or for anti-fascist strategy. Thus he critiques the Italian marxist Arturo Labriola for his construction of 'the manifestations of imperialism, the struggle to subdue other countries, the struggle for expansion, as things we must accept because they are leading us towards socialism'.32 (These were criticisms which were also made in more trenchant terms by Antonio Gramsci. ${ }^{33}$ ) But, while Togliatti challenges Labriola's legitimisation of the Italian colonial project, he doesn't really interrogate the relations between this project and fascism. By contrast, such geographies of anti-fascist struggle are foregrounded by figures such as Hughes and Padmore and in the testimonies and writings of many African Americans who volunteered with the International Brigade. These connections and relations were developed primarily through the following key interventions.

First, African American volunteers frequently came to the fight against fascism in Spain through active involvement in opposing Mussolini's invasion of Ethiopia. As volunteer Albert Chisholm noted, he 'signed up to go to Spain because in that era fascism was on the march. Italy attacked the country of Ethiopia'. ${ }^{34}$ That Chisholm positions Ethiopia as a 'sort of a primitive society', but nonetheless one that 'black people throughout the world could look up to because it was governed by a black administration', suggests some of the uneven geographies through which such diasporic connections were forged and imagined.

Secondly, key black internationalist intellectuals such as Langston 
Hughes and George Padmore engaged seriously with the 'racialised' politics of fascism. Thus Hughes, who reported on the Spanish Civil War for the Baltimore-based African American, noted in a speech at the Second International Writers Congress in Paris in July 1937 that people could now view fascism on a world scale: 'Hitler in Germany with the abolition of labor unions, his tyranny over the Jews, and the sterilization of the Negro children of Cologne; Mussolini in Italy with his banning of Negroes on the theatrical stages and his expeditions of slaughter in Ethiopia'. ${ }^{35}$ In similar terms George Padmore developed an analysis of what he termed 'colonial fascism' in his writings on the British Empire. ${ }^{36}$

Thirdly, for Hughes fascism was not seen as something that was merely distant. He argued that: 'We [African Americans] are the people who have long known in actual practice the meaning of the word fascism - for the American attitude toward us has always been one of economic and social discrimination'. ${ }^{37}$ Many African American volunteers in Spain linked the conflict to struggles within the United States over white supremacy, reflecting in part their own diverse experiences of gendered and racialised violence. Thus James Yates, a volunteer from Mississippi, who had travelled to Chicago and New York before going to Spain, recalls that when he saw speakers in Union Square in New York talking on the rise of fascism in Europe, he recalled seeing lynchings in his youth in Mississippi. ${ }^{38}$ These diverse black internationalist interventions, then, reconfigured the terms on which fascism and anti-fascism were constituted.

\section{African American communism and the construction of anti-fascist solidarities}

Writing in his autobiography From Mississippi to Madrid, James Yates observes that it 'is a sad indictment of American politics that the only political platform that seemed to recognise the reality of my life belonged to the Communist Party'. ${ }^{39} \mathrm{He}$ cites the party's argument that 'the Negro people suffer doubly', as the ' $[\mathrm{m}]$ ost exploited of working people, they are also the victims of Jim Crowism and lynchings'. Yates recalls that 'those words were heady stuff, and contends that ' $[\mathrm{t}]$ hose who have difficulty understanding this have never walked in my shoes'. He also draws attention to the party's commitment to political prisoners such as Angelo

Twentieth Century Communism - Issue 7 
Herndon and the Scottsboro Boys and to full equality for the 'Negro people'.

By the mid-1930s, then, the CPUSA had acquired a reputation for being at the forefront of struggles against racism and for black liberation in the United States. This position was cemented by its commitment to multi-racial political organising practices, the adoption of the 'black belt nation thesis', and its leading role in major transnational organising, most notably the campaign to free the Scottsboro' Boys. ${ }^{40}$ The CPUSA was the central political institution through which African American volunteers were enrolled into the International Brigades. 'African American brigadists', Robin Kelley writes, 'were a diverse bunch that included Northerners and Southerners, the college-trained and semiliterate, unemployed workers and self-styled intellectuals'. ${ }^{41} \mathrm{He}$ continues that 'most were Party members or supporters who interpreted communism though the lenses of their own cultural world and the international movement of which they were a part'.

Kelley stresses that African American communists in the 1930s used the CPUSA to develop political presence, space and dignity, despite communist party paternalism towards black communists. ${ }^{42}$ The significance of black party membership should not be underestimated, nor, as the dynamic strategies of George Padmore and Garan Kouyaté attest, should black party members be seen as 'Comintern' dupes. Black members reported, however, diverse experiences of the party. Hosea Hudson, a prominent African American Alabama communist, recalled that he 'found this Party, a party of the working class, gave me rights equal with all others, regardless of color, sex, or age or educational standards. I with my uneducation could express myself without being made fun of by others who could read well and fast, using big words'. ${ }^{43}$ Other activists had a much more difficult relation to the party. Oscar Hunter, a black party member who fought in Spain, recollected that: 'I was always in trouble. I was always in trouble, I didn't have the correct line, I didn't have the correct approach, I didn't have this, I didn't have that.' ${ }^{44}$

While Hudson and Hunter's accounts offer contrasting experiences of party life, their testimonies suggest the importance of the forms of interracial interaction and organising facilitated by the CPSUSA, even if the conduct of this organising could be fraught and contested. Mark Naison 
notes that while the Harlem communist party drew 'its most talented early recruits from Harlem nationalist circles,' it 'gradually evolved toward a policy which insisted on complete integration of blacks and whites in every aspect of Party life'. This inter-racialism 'coincided with the theoretical affirmation of a "Black Belt Nation", but this 'nationalist impulse remained largely confined to theory', and from ' 1929 on, being a black Communist in Harlem meant meeting, studying, protesting and socialising with whites'. Naison emphasises that for 'blacks and whites in the Party - and for non-Communists who came in contact with it - this constituted a new experience, one which evoked tension, confusion, curiosity and excitement'. ${ }^{45}$ This commitment to inter-racial organising and solidarity directly influenced the cultures of the International Brigade. It also shaped the articulations of anti-fascism developed by African American volunteers in the brigade.

Yates notes how the decision to fight in Spain was much more difficult to come to than a decision to go to Ethiopia. He argues that he 'had been more than ready to go to Ethiopia, but that was different. Ethiopia, a Black nation, was part of me'. ${ }^{46} \mathrm{He}$ signals the inspiration of the political situation in Spain, although in terms which elide the contested politics of the left in Spain, and arguably portray a rather romantic and unitary sense of the Spanish people. He argues:

I was just beginning to learn about the reality of Spain and Europe, but I knew what was at stake. There the poor, the peasants, the workers and the unions, the socialists and the communists, together had won an election against the big landowners, the monarchy and the right wingers in the military. It was the kind of victory that would have brought Black people to the top levels of government if such an election had been won in the USA. A Black man would be Governor of Mississippi.

Yates's account gives a sense of both the difference and connectedness of the struggles in Spain and Ethiopia. This shift in identification from Ethiopia to Spain signals an inventive and productive engagement with anti-fascism. Central here is an ongoing engagement with the shifting maps of grievance through which fascism was contested. Thus Yates

Twentieth Century Communism - Issue 7 
connects the conflict in Spain both to struggles against racism in the US as well as to anti-colonial politics in relation to Ethiopia. He also signals the important inspiration of the political changes that had happened in Spain before the outbreak of the civil war. These maps of grievance generated productive solidarities between struggles in Spain, Ethiopia and the US.

Vaughn Love, an African American volunteer from Dayton, Tennessee, recalled that his friends told him that it was 'irrational' to go to Spain 'when so much was needed in the fight for Negro rights in this country'. He contended, however, that 'the battle for Negro rights, human rights and the future of civilization itself was at stake in Spain'. ${ }^{47}$ This way of configuring anti-fascism was a significant political intervention. It was dissonant with forms of black nationalism that at times forged 'unanimistic solidarities' in relation to Ethiopia. ${ }^{48}$ Paul Gilroy uses this term to theorise forms of solidarity constituted through homogeneous notions of 'race', deploying it to analyse the forms of political culture generated through Marcus Garvey's Universal Negro Improvement Association. These generated black diaspora politics that were constituted and formatted in part through Garvey's stress on racial homogeneity and purity. ${ }^{49}$ Garvey advocated a translocal imaginary of black men defined by racial purity including, for example, through anti-semitic narratives. ${ }^{50}$ Such a unanimistic vision of solidarity was mobilised by Garvey in relation to the struggles over Ethiopia. He argued that 'The Emperor of Abyssinia allowed himself to be conquered by playing white', and praised Mussolini as an 'astute diplomat and expert statesman'. ${ }^{51}$

Such 'unanimistic solidarities' put pressure on the imaginative geographies of solidarity, and on the terms on which anti-fascism was articulated. Key tensions emerged in the US, as some Garveyite organisations mobilised around the boycott of Italian businesses in Harlem and elsewhere. ${ }^{52}$ These boycotts drew on broader black resentment against Italian Americans. ${ }^{53}$ There were riots and street brawls between African Americans and Italian Americans, including violence after the defeat of the boxer Primo Carnera by Joe Louis on 26 June 1935.54 The leading African American communist James Ford noted that in the 'Harlem upsurge' of 19 March 1935, 'the Negro people expressed their hatred of Italian fascism and its plans for war against their Ethiopian brothers. 
Italian liquor shops were smashed with cries of "Down with Mussolini!". 55 Such attacks against Italian-Americans, however, were not un-contested. Mark Naison, in his study of Harlem communists in the 1930s, argues that black communists in Harlem shaped a solidaristic, multi-ethnic opposition to fascism through forging alliances with anti-fascist Italians in New York and through contesting the targeting of Italian merchants.

Communists such as Abner Berry, Sol Harper and William Fitzgerald joined with 'Capt King and I. Alleyne of the UNIA and Arthur Reid of the African Patriotic League' in a 'Provisional Committee for the Defense of Ethiopia' (PCDE) that brought together a number of Harlem organisations, 'representing varying degrees of antagonism to all whites'. ${ }^{56}$ They 'tried to persuade members of the committee that antifascist whites, particularly antifascist Italians, be involved in the campaign, and that Italian merchants in Harlem not be a target of the committee's attacks'. But Gayle Plummer contends that Naison overstates the importance of communists in the PCDE arguing that its vitality 'owed more to the continued strength of Garveyite sentiments than to any other factor'. ${ }^{57}$ What is perhaps more significant, however, is a consideration of the productive nature of the exchanges and relations forged between different groups through the PCDE.

Tensions over how to construct anti-fascist solidarities intersected with longstanding antagonisms and distrust between Garveyites and communists. ${ }^{58}$ Pointing to picket lines in front of the Italian consulate by the Italian workers club, and demonstrations in East Harlem against the fascist propaganda film The Man of Courage, black communists argued that 'many Italian-Americans were refugees from fascism and would participate in a struggle against Mussolini's government'. ${ }^{59}$ Some Garveyites also supported this position. S.A. Haynes, a ranking Garveyite and staff writer for the Philadelphia Tribune, 'attacked the boycotts of Italian-American merchants as misguided', arguing that 'Italians and persons of Italian descent in America ... were not responsible for Mussolini's imperialism'. ${ }^{60}$ This suggests that the political practices of Garveyism could also exceed the narrow forms of racialised politics articulated by its iconic leader. The integrity of communist support was dramatically undermined, however, by the failure of Max Litvinov, the Soviet Union's delegate to the League of Nations meeting of April 1935,

Twentieth Century Communism - Issue 7 
to condemn Italian aggression. ${ }^{61}$ This was emblematic of the broader subordination of anti-colonial politics to the geo-political and economic interests of the USSR. ${ }^{62}$

Solidarities with Italian anti-fascists were constituted through challenging the maps of grievance which shaped 'unanimistic solidarities'. Adam Clayton Powell Jr argued that the 'militancy of Garveyism must be carried on, but we must move within a greater program ... the union of all races against the common enemy of fascism'. ${ }^{63}$ These struggles over different ways of envisioning the geographies of such solidarities were integral to different articulations of anti-fascism. It also suggests how such solidarities were generative and refashioned political trajectories. These multiple trajectories and connections were integral to the solidarities and forms of cosmopolitan internationalism shaped through the International Brigades. ${ }^{64}$ As Helen Graham notes, in 'racial and cultural as well as political terms ... the heterogeneity of the Brigades made them a living form of opposition to the principles of purification and brutal categorization espoused by fascism and above all, by Nazism'.65

The solidarities forged between these international volunteers were generated through small acts and friendship, as well as shared political convictions. These produced forms of cosmopolitan internationalism which were shaped through articulations and linkages between activists with different trajectories. They also generated forms of interaction which cross-cut the national divides that can become entrenched and reproduced through more nation-centred articulations of internationalism. Thus Oscar Hunter speaks affectionately in an oral history testimony of an English brigader called Topsol (Tapsell). ${ }^{66} \mathrm{He}$ recalls: 'one night with some Englishmen going home, they were going home and I was going to Albacete, and one of them was named Topsol and all the way down, I'll never forget, he sang all these filthy English ballads ... Topsol was something. ${ }^{67}$ Hunter's account of his friendship with Topsol emphasises that the brigade nourished very different relations to the racial politics of the US, though his account suggest that these friendships were forged through particular forms of masculinity. Hunter's reference to sailor's songs invokes the importance of seafarers to the cultures of the International Brigades. The National Maritime Union 
(NMU), for example, was one important inter-racial union which arguably shaped the diverse make-up of the Fifteenth Brigade.

The National Maritime Union was one of a number of institutions close to the CPUSA that developed a strong if uneven commitment to interracial organising in the 1930s. Thus Ferdinand Smith, a Jamaican-born communist and leading official in the NMU, noted in a pamphlet written in 1942 that the members of the NMU have learned the truth of Karl Marx's observation that 'Labor with a white skin can never be freed while labour with a black skin is branded'. He noted that we 'learned it on the picket line when we were carrying on the struggle to organize; we have learned it over and over again since'. ${ }^{68}$ Jesse Gray, a long time NMU radical, noted in a discussion with Harry Haywood that the NMU was 'like another world'. He noted that if you've 'always lived in the south in the US where racism was so sharp ... to go to NMU where black and whites were on the ship, they were together, worked together, it was a real big thing'. ${ }^{69}$

Involvement in maritime labour and unions like the NMU was a common experience of many volunteers in the ALB both before and after their involvement in Spain. Eluard Luchell McDaniels, known as 'El Fantastico' during his time with the brigade, spoke on behalf of the National Union of Marine Cooks and Stewards at the National Convention of Maritime Unions in May 1946, denouncing the anti union activities of the War Shipping Administration and the Coast Guard in 'places like Okinawa'. ${ }^{70}$ In 1941 he led a protest at a segregated lunch counter in Durban while on his return from active service in the Second World War. ${ }^{71}$ McDaniels's account of his time in Spain notes the differentiated trajectories of volunteers in their struggles against fascism. As someone who had grown up on the West Coast of the US and been adopted by a wealthy bohemian family, he notes that there were strong class and regional differences between himself and other black brigaders. ${ }^{72} \mathrm{He}$ recounts how, although the other volunteers 'treat me nice' he felt 'different' from 'Negroes ... of the East', suggesting tensions between African Americans of different class backgrounds and from the East and West Coast.

Like other rank-and-file black volunteers, McDaniels was coruscating in his criticism of Harry Haywood's leadership. Thus he argued that 'he got messed up too much'; there were 'too many good times and not enough leadership'; and Haywood 'spent most of his time around women and 
dressed up and stuff like that'. ${ }^{73}$ Haywood served as an 'assistant Regimental Commissar', but was ordered back to the United States in the autumn of 1937, and removed from the politburo of the CPUSA in May 1938 as a result of charges of cowardice in Spain. In Haywood's view he was ostracised for critiquing the 'brutal incompetence and irresponsibility' of General Gal and Lieutenant Colonel Vladimir Copić, the Fifteenth International Brigade commander and commissar at the Battle of Jarama. ${ }^{74}$ This version of events was contested by other brigaders, but, whatever the case, Haywood he described his time in Spain as a 'personal crisis'. ${ }^{75}$

In line with some of the fraught inter-racial politics of the CPUSA, the terms of the inter-racial politics of the brigade were also contested. Salaria Kee, an African American nurse who served with the Second American Medical Unit, recalls in vivid terms the entrenched prejudice she encountered from senior medical staff from the United States South while in Spain. ${ }^{76}$ Lieutenant Conrad Kaye told Paul and Eslanda Robeson during their visit to the front that there had been tensions with southern white Americans and the British on the 'Negro question'. Kaye noted that 'the really difficult ones [were] the British', who refused 'to eat in dining rooms with the Negroes' and had to be 'drastically re-educated, because neither the Spaniards nor the International Brigade will tolerate such heresy.' 77 This emphasises how racist conduct could be challenged through the International Brigades, but also problematises some of the practices through which solidarities were constructed in Spain. Such practices of solidarity are further unsettled by interrogating the negotiation of the colonial geographies of Spain.

\section{The limits of black internationalism}

In his poem 'Letter from Spain addressed to Alabama' Langston Hughes interrogates the relationship between Moroccan struggles for independence and the Spanish Civil War. One of a number of poems he wrote while in Spain in 1937 for the African American, this was first published in Volunteer for Liberty, the main publication of the Fifteenth International Brigade. The poem is structured around a conversation between an 'African American volunteer' in the Lincoln Battalion and a captured 'wounded Moor'. The 'Moor' is constructed in the poem as a conscript 
who had been forced to fight, to 'join the fascist army/ and come across to Spain'. ${ }^{78}$ Luis Girón Echevarriá contends that Hughes's Spanish Civil War poems are generally structured by an equation of the 'ideological struggle between democracy and fascism as a conflict between good and evil, likewise depicting the combatants as either virtuous comrades or villainous adversaries'. ${ }^{79} \mathrm{He}$ notes, however, that Hughes was disturbed 'by the one component that did not fit into this neat arrangement of opposites: the North African troops serving with Franco's army'. This context was arguably disruptive of the black internationalist anti-fascism that structured Hughes's analysis in 'Too Much of Race' presented, as noted above, at the Second Writers' Congress Against Fascism in Paris. His poem, however, locates the struggle for Moroccan independence as part of such a black internationalist radical imaginary. By framing the poem as a letter addressed to Alabama, Hughes makes the poem an intervention in the relations between the Spanish Civil War, Moroccan struggles for independence and racialised oppression in the American South. It was also decidedly against the grain of some left political interventions which were very hostile to 'Moors'; 'Moors and worse than Moors' the Scottish communist poet Hugh MacDiarmid was to write in his poem 'An English War-Poet'. 80

For Hughes, whilst the African American and 'Moor' are opposed through their role in the conflict, he envisions solidarities being constructed between them based on a shared anti-colonial and antifascist position which would result in shared liberation through a Republican victory. Hughes notes that 'I looked across to Africa / and seed foundations shakin':

Cause if a free Spain wins this war, The colonies, too, are free -

Then something wonderful'll happen

To them Moors as dark as me.

I said, I guess that's why old England

And I reckon Italy, too,

Is afraid to let a worker's Spain

Be too good to me and you -

Twentieth Century Communism - Issue 7 
Cause they got slaves in Africa -

And they don't want 'em to be free.

Listen Moorish prisoner, hell!

Here, shake hands with me!

Hughes positions the exchange between the two soldiers as one that could be potentially productive of a very different end - one of a fight for African independence against coloniser nations such as Britain and Italy. While the poem is framed by an imaginary of anti-colonial internationalism, the resolution in the final stanza troubles this imaginary. The poem ends with the death of the 'wounded Moor' - and this is accompanied by a stark image of disconnection:

I knelt down there beside him,

And I took his hand,

But the Wounded Moor was dyin'

And he didn't understand.

This ending invokes the fraught relations between Moroccan struggles and the position of Republicans during the Spanish Civil War. It also emphasises the considerable pressures that were placed on the formation of solidarities between those fighting on the Republican side and Moroccan anti-colonial struggles.

While Hughes's poem is open to the terms of these relations being transformed, other black internationalist writers and political figures were more uncompromising. George Padmore thus wrote in harsh terms of the implications of the failure of the Spanish republic to develop an anti-imperialist stance in relation to Morocco in his contribution to the controversial Left Review pamphlet Authors Take Sides on the Spanish War, published in 1938 and edited by Nancy Cunard. He noted that:

The sympathy of Africans and other colonial peoples naturally goes out to the toiling masses of Spain in their heroic struggle against Fascist-barbarism, for they have not forgotten Abyssinia. And precisely because of this, it is so regrettable that democratic Spain, by failing to make an anti-imperialist gesture to the Moors, played 
into the hands of Franco. This should be a reminder to the European workers that: 'No people who oppress another people can themselves be free. ${ }^{\prime 1}$

Padmore's contribution foregrounds the contested geographies through which anti-fascism was constituted and articulated. He draws out the important continuities between anti-fascism in Ethiopia and Spain, and relates the solidarity of Africans and colonial peoples for the cause of Spain to the Spanish not forgetting 'Abyssinia'. His support for antifascism in Spain, however, is tempered by strong criticism of the republic's position in relation to Morocco. In Africa and World Peace, Padmore commented that 'had the People's Front Government made a gesture to the Moors by pointing out to them that the new regime was the defender of their economic and social interests, then we feel certain that Franco would never have been able to have deceived these African tribesmen into supporting his cause'. ${ }^{82}$

The Jamaican novelist Claude McKay, an influential figure on early debates in Moscow and beyond on the relations between communism and black politics, expressed the consequences of this failure. He argued that 'Spanish reaction first strengthened itself in Morocco by forcing the young Republic to betray the native workers in the colony before it began its offensive against the Spanish workers at home'. For McKay the 'lesson' was 'plain', as the title of his article indicates: 'Native Liberation Might Have Stopped Franco's Revolt'. ${ }^{83}$ The republican government, however, failed to develop an anti-colonial position. This facilitated the recruitment of Moroccan soldiers to fight as part of Franco's forces.

These colonial relations had, however, been contested by independence struggles and by the Spanish left. In 1909 a general strike was called in Catalonia 'to protest at the flare up in the colonial war in Morocco through the second Rif war and especially at the sending of reservists'. ${ }^{84}$ Already existing connections between North African and European left movements were utilised as possible resources for anti-imperial solidarities during the Spanish Civil War. The Étoile Nord Africain (ENA), Algeria's 'first mass-based leftist party', which was founded by Algerian immigrants in Paris, was significant in this regard. ${ }^{85}$ Representatives from the ENA had spoken at the conference of the League Against Imperialism

Twentieth Century Communism - Issue 7 
in Brussels in 1927. On 31 July 1936 a resolution organised by the ENA in Paris declared that those present 'Send their fraternal greetings to their Muslim brothers of Morocco, who are suffering under the boot of Fascism, and call on them to place themselves on the side of the Republicans of the Spanish Popular Front, against the rebel generals'.$^{86}$

The Moroccan rebels had their own histories of internationalist connections and support. In August 1909 the militant anti-colonial Indian activists M.P.T. Acharya and Sukh Sagar Dutt, prominent figures in the Ghadar movement, the transnational Indian anti-colonial movement, had left London for Gibraltar en route to Morocco. They had intended to join the rebels in the Rif against the Spanish, 'with a view to gaining experience in military practice', and also 'to draw the attention of the Muhammedans in Morocco to the condition of their co-religionists in India'. ${ }^{87}$ Dan Breen, a key leadership figure in the IRA during the Irish War of Independence and ensuing Civil War, had considered joining up with the Rif Rebellion in Morocco, after an emissary of Abd-El-Krim had 'offered him a significant sum of money to come and help in the rebellion against Spain'. ${ }^{88}$

There were also significant communist links between Spain and Morocco. As Alma Heckman notes: 'Spanish Leftists in cities such as Meknes and Casablanca sparked the invigoration of Leftist organisations in those locales as well as others. The Spanish Communist Party remained organised and active throughout the 1930s, 40s and 50s in Morocco, often collaborating with the PCM' ${ }^{89}$ Further, there was a significant cultural presence of communists in cities such as Meknes: 'the 1930s alone in Meknes witnessed hundreds of Spanish Communist fundraisers, dances, film projections and more'; and there was 'a particularly strong Jewish presence'. As Hakim Adi notes, however, the North African colonies were 'generally not included in the Comintern's conception of the Negro Question'. ${ }^{90}$ It was figures in the anarcho-syndicalist CNT and trotskyist movement that would play particularly significant roles in attempting to shape an anti-imperial internationalism in relation to Spain and Morocco.

The anarcho-syndicalist CNT prepared with 'certain Moroccan groups' plans for 'an insurrection in Spanish Morocco'. ${ }^{91}$ Spanish and French trotskyist activists argued for the necessity of links between revolution in Spain and North Africa. ${ }^{92}$ An interview with Moroccan leaders 
by Nancy Cunard was published in the Afro-American..$^{93}$ The French trotskyist leader Jean Rous noted that in September 1936 'a comrade of the Fourth International arrived in Barcelona along with some Moroccan nationalist leaders, who undertook to foment a revolt against Franco in Spanish Morocco on condition of certain political assurances relating to the liberation of Morocco. ${ }^{94}$ The comrade was David Rousset, a member of the political bureau of the Parti Ouvrier Internationaliste (POI), the French section of the Fourth International.

Rousset was in Fez in 1936 to construct links with the Moroccan Action Committee on behalf of the POI when Franco and his 'brutalized and interventionist officer elite', which had fought and won the colonial war in Spanish Morocco, launched their coup against the Spanish republic. ${ }^{95}$ Rousset brought two members of the Moroccan Action Committee, Mohammed Hassan Wazzani and Omar Abjelil, to 'negotiate first of all with the Central Committee of the Anti-Fascist Militias in Barcelona, and then afterwards with Largo Caballero'. Rousset notes that the Moroccans proposed the following principle: 'we are ready they said to start a military uprising in the Spanish Zone in the Rif, but we will only do it on one express condition that you recognise our independence'. ${ }^{96}$ Negotiations broke down, however, over the government's refusal to recognise the independence of Morocco' ${ }^{97}$

Accounts of volunteers in the Fifteenth International Brigade, unsurprisingly, dwell more directly on the antagonistic relations constructed with Moroccan soldiers, reflecting their location in opposing sides of the conflict. Nonetheless there is some recognition of the legitimacy of Moroccan struggles for independence. Vaughn Love devotes considerable space in his unpublished autobiography $A$ Closer Look to discussion of relations with Moroccan fighters and political contexts. He contends that the 'story would have been different if the cause of democracy in Spain had been concerned about the Moroccan people also, but that is a lesson that the lovers of democracy must learn'. ${ }^{98}$ Abd-El-Krim's struggles against the French/Spanish were well known in African American radical circles. A portrait of the 'Moroccan revolutionary' was hung alongside Toussaint Louverture, Denmark Vesey, Nat Turner and Sun Yat-sen at the founding convention of the American Negro Labour Congress on the south side of Chicago in 1925.99

Twentieth Century Communism - Issue 7 
This recognition of the way that there could have been different relations between Spain and Morocco is tempered, however, by some pretty unpalatable representations of Moroccan troops. Thus Love argues that Moroccan soldiers commanded by General Yagüe in the Army of Africa 'were undoubtedly the most ignominious cannon fodder that was ever used on any battlefield'. ${ }^{100} \mathrm{He}$ also recalls that in the closing days of the battles around Brunette:

... we ripped the fascist divisions to shreds, especially General Yagüe's African Legions. These were the hated and despised dregs of Spanish Morocco who were the watchdogs over the Spanish Colonial Empire and the main strength of the Military rebellion against the Republican government.

This testimony emphasises some of the limits to the constitution of black internationalisms. ${ }^{101}$

The testimony of Bill Bailey, collected for John Gerassi's book Premature Anti-Fascists, offers more evidence of such tensions. Bailey was a renowned West Coast seafarers' organiser who had impeccable antifascist and organising credentials. He was among the group of seafarers and other radicals who had torn the swastika off the Bremen while it was moored in New York in 1935. He also had a reputation for commitment to multi-ethnic organising in opposition to International Seamen's Union. ${ }^{102}$ But his account of leaving Spain and returning to the US via France includes a heavily racialised description of his journey through France.

Bailey recalls that International Brigaders were transported through France in 'closed' trains so that their supporters could not see them or offer them support. He describes being on 'closed' trains as an 'insult' that was compounded by being guarded by Senegalese soldiers. He articulates this as 'the highest insult one can get in coming back': 'Closed trains, can't get out, can't talk to anybody, on the outside. And being "guarded" by the guys you were fighting.' 103 'And on top of that they used Senegalese guards. They were the guards, like the Moro' guards, the black guards, standing at attention at the depot.' Here Bailey makes a notable slippage between Moroccan and Senegalese guards. Further, there is a strong sense 
of Bailey resenting the fact that it was black soldiers guarding him. This recalls the terms of debate on the left prompted by Morel's pamphlet Horror on the Rhine. The response of the left to the use of Moroccan soldiers to suppress labour unrest was a rash of 'black scourge' articles, published by figures such as George Lansbury in the Daily Herald. Claude McKay argued strongly against such a position on the left and notes in his autobiography that 'maybe I was not civilized enough to understand why the sex of the black race should be put on exhibition to persuade the English people to decide which white gang should control the coal and iron of the Ruhr'. ${ }^{104}$ McKay's trenchant critiques of Lansbury emphasise ongoing challenges to the power-laden geographies of colonialism that are reproduced rather than challenged in Bailey's account.

\section{Conclusions}

In his book In the Cause of Freedom, Minkah Makalani argues that radicals such as Cyril Briggs, Grace Campbell and Richard Moore from the African Blood Brotherhood came to the communist movement as 'activist-intellectuals willing to stretch the boundaries of a political theory so that it might address racial oppression and colonialism.' ${ }^{105}$ Makalani's focus on the ways that such boundaries and limits of left political theorising were stretched and reconfigured allows something of the generative spatial politics of communist internationalism to emerge. Rather than being confined within narrow core-periphery models where key Comintern figures had all the power in defining how communist politics operated, it opens up some of the contested practices through which solidarities and articulations were shaped. It also enables a foregrounding of the agency of black and Asian radicals and communists in shaping some of the terms on which communist internationalism was imagined and articulated.

This paper has argued in similar vein that diverse black internationalist interventions stretched and reconfigured the terms on which fascism was theorised and opposed. Some black internationalist intellectuals and activists used the spaces afforded by communist internationalism to provide space for political analyses which connected anti-fascism to anti-colonial politics and analysis. These interventions and the political solidarities they generated offered important challenges to ways of thinking about fascism

Twentieth Century Communism - Issue 7 
and anti-fascism which constructed them in bounded European terms. The ways in which African American volunteers connected anti-fascism to struggles against racial oppression in the United States could also be rather dissonant with the construction of anti-fascism as a kind of left patriotism by CPUSA leaders such as Earl Browder. ${ }^{106}$

Helen Graham argues that of the approximately 35,000 International Brigaders who fought in Spain, the great majority were political exiles who had been forced to leave countries such as Germany, Austria and Italy. She argues that the 'forms of left internationalist politics' they created 'dovetailed with their own diasporic condition, signalling a powerful corrective to the other literally murderous, forms of politics inhabiting their own countries'. This article, by contrast, has sought to engage with a different set of diasporic politics in relation to the Spanish Civil War. Through tracing forms of internationalist politics which produced politicised articulations of blackness I have argued for ways of thinking more seriously about the need to scrutinise different aspects of the colonial geographies of the conflict and how they were negotiated through various lefts. Through doing so I have sought to foreground not just some of the imaginative connections and solidarities forged through such political practices, but also some of the ways these exerted pressure on the forms of left internationalism they constituted.

Thanks are due to the very useful feedback and engagement from the workshop on Towards Transnational Communist History where this paper was first presented and to the helpful comments of two reviewers. The research the paper draws on was funded by a British Academy Small Grant on 'Black Internationalism and the Spatial Politics of Anti-Fascism?

\section{Notes}

1. Harry Haywood, Black Bolshevik: Autobiography of an Afro-American Communist, Chicago: Lake View Press, 1978, p206. On Murray and Larkin see Emmet O'Connor, Reds and the Green: Ireland, Russia and the Communist Internationals, 1919-1943, Dublin: University College Dublin Press, 2004, esp. pp164-6.

2. Haywood, Black Bolshevik, p622.

3. S. Sills, 'Abraham Lincoln Brigade', in $\mathrm{M}$ Buhle et al (eds), The 
Encyclopedia of the American Left, Chicago: St James's Press, 1990, pp2-4. Collectively these battalions are now popularly known as the Abraham Lincoln Brigade; this nomenclature arose, however, out of the Veterans of the Abraham Lincoln Brigade organisation founded after the war.

4. S. Chari and K. Verdery, 'Thinking between the posts: postcolonialism, postsocialism, and ethnography after the Cold War', Comparative Studies in History and Society, 51 (1), 2009 6-34, p29.

5. Haywood, Black Bolshevik, pp148-75; R Kelley, Hammer and Hoe: Alabama Communists in the Great Depression, Chapel Hill: University of North Carolina Press, 1990.

6. K Baldwin, Beyond the Color Line and the Iron Curtain: Reading Encounters Between Black and Red, 1922-1963, Durham, North Carolina: Duke University Press, 2002, p85.

7. Mark Naison, Communists in Harlem During the Depression, Chicago, University of Illinois Press, 2005.

8. W.E. Perkins, 'Black Nation', in Buhle, Encyclopedia, p95.

9. Perkins, 'Black Nation'; Haywood, Black Bolshevik, pp218-44.

10. M. Makalani, In the Cause of Freedom: Radical Black Internationalism From Harlem to London, 1917-1939, Durham: University of North Carolina Press, 2011, p73.

11. Cedric Robinson, Black Marxism: the Making of a Black Radical Tradition, London, Zed Books, 1983.

12. Makalani, In the Cause of Freedom, p56.

13. W. James, Holding Aloft the Banner of Ethiopia: Caribbean Radicalism in Early Twentieth Century America, London: Verso, 1998, p155; see also Robinson, Black Marxism.

14. Makalani, In the Cause of Freedom, pp62-3.

15. Ibid, p80; see also Sobhanlal Datta Gupta, 'History re-examined: antiimperialism, the Communist Party of India and international communism', in Dianne Kirby et al (eds), John Saville: Commitment and History: Themes from the life and work of a socialist historian, London: Lawrence \& Wishart, 2011, pp113-31.

16. '[M N] Roy's Draft and Adopted Text of Supplementary Theses' in G. Adhikari (ed.), Documents of the History of the Communist Party of India, Volume One, 1917-1922, People's Publishing House, 1971, pp178-88, p183.

17. Makalani, In the Cause of Freedom, p5. 
18. B.H. Edwards, The Practice of Diaspora, Harvard: Harvard University Press, 2003, pp2-3.

19. F. Ottanelli, The Communist Party of the United States: From the Depression to World War II, New Brunswick: Rutgers University Press, 1991; Ottanelli, 'Anti-fascism and the shaping of national and ethnic identity: Italian American volunteers in the Spanish Civil War', Journal of American Ethnic History 27 (1), 2007, pp9-31.

20. Edwards, Practice of Diaspora, p198.

21. T. Brennan, Wars of Position: The Cultural Politics of Left and Right, New York: Colombia University Press, 2006; Craig Calhoun, 'The class consciousness of frequent travellers: towards a critique of actually existing cosmopolitanism', in D. Archibugi (ed.), Debating Cosmopolitics, London: Verso, 2003, pp86-116.

22. N.G. Schiller, 'Old baggage and missing luggage: a commentary on Beck and Sznaider's 'Unpacking cosmopolitanism for the social sciences: a research agenda', British Journal of Sociology, 61(1), 2010, pp413-20.

23. Perry Anderson, 'Internationalism: a breviary'. New Left Review, 14, 2000, pp5-25; Geoff Eley, Forging Democracy: the History of the Left in Europe, 1850-2000, Oxford: Oxford University Press, 2002; Raphael Samuel, The Lost World of British Communism, London, Verso, 2006 edn.

24. On Padmore, see Hakim Adi, Pan-Africanism and Communism: the Communist International, Africa and the Diaspora, 1919-1939, New Jersey, Africa World Press, 2013, F. Baptiste and R. Lewis (eds), George Padmore: Pan-African Revolutionary, Kingston: Ian Randle Publishers, 2009; Bill Schwarz, 'George Padmore' in Schwarz (ed.) West-Indian Intellectuals in Britain, Manchester: Manchester University Press, 2003, pp132-52; J. Hooker, Black Revolutionary: George Padmore's Path from Communism to Pan-Africanism, London: Praeger, 1967; George Padmore, Pan-Africanism or Communism: The Struggle for Africa, London: Dennis Dobson, 1956; Susan Pennybacker, From Scottsboro to Munich: Race and Political Culture in 1930s Britain, Princeton: Princeton University Press, 2009, pp66-102.

25. Edwards, Practice of Diaspora, p244, G. Kouyaté, 'Black and white seamen organize for struggle', Negro Worker, 1: 12, 1931, pp19-20, see also J. Derrick, Africa's 'Agitators': Militant Anti-Colonialism in Africa and the West, 1918-1939, London: Hurst \& Company, 2008, pp221-6.

26. See also Derrick, Africa's Agitators, pp281-304. 
27. Makalani, In the Cause of Freedom, p181.

28. Edwards, Practice of Diaspora, p264.

29. Paul Gilroy, Against Race: Imagining Political Culture Beyond the Color Line, Cambridge, MA: Harvard University Press, 2000, p300.

30. Palmiro Togliatti, Lectures on Fascism, New York, International Publishers, 1976, p43.

31. Ibid, p20.

32. Ibid, p107.

33. A.K. Patnaik, 'Gramsci and the Postcolonial World', Economic and Political Weekly, 14 September 2013, pp25-7.

34. Albert Chisholm, 'Testimonies: Albert Chisholm', in D.D. Collum (ed.) African Americans in the Spanish Civil War: 'This Ain't Ethiopia, But It'll Do', New York: G.K. Hall \& Co, 1992, pp145-50.

35. Langston Hughes, 'Too Much of Race' in Collum, African Americans, p107.

36. George Padmore, 'Fascism in the Colonies', published originally in Controversy (1938) and available at: www.marxists.org (last accessed 21 October, 2013).

37. Hughes, 'Too Much of Race', p107. Dorothy Healey notes her reservations about the use of the term 'fascism' in relation to the US in the 1930s in the discourses of the CPUSA; see Dorothy Healey and Maurice Isserman, California Red: A Life in the American Communist Party, Chicago: University of Illinois Press, 1993.

38. James Yates, From Mississippi to Madrid, Greensboro, NC: Open Hand, 1988, p87.

39. Yates, From Mississippi To Madrid, p98.

40. Naison, Communists in Harlem, p13.

41. Robin Kelley, Race Rebels: Culture, Politics and the Black Working Class, Free Press 1996, p124.

42. See Robin Kelley, Hammer and Hoe: Alabama Communists in the Great Depression, Chapel Hill: University of North Carolina Press, 1990, 92-116. For an application of this argument to the activities of black communists in 1930s Cardiff see David Featherstone, Solidarity: Hidden Histories and Geographies of Internationalism, London, Zed Books, chapter 3.

43. N.M. Painter, The Narrative of Hosea Hudson: The Life and Times of a Black Radical, New York: W.W. Norton, 1994, p180.

44. Tamiment Library and Robert F. Wagner Labor Archives, New York

Twentieth Century Communism - Issue 7 
University Abraham Lincoln Brigade Archive (hereafter ALBA), 18.3.7, p18, emphasis in original.

45. Naison, Communists in Harlem, p. xviii.

46. Yates, From Mississippi to Madrid. For a useful discussion of some of the fractured left political context in Spain, see J. Paniagua, 'Republicans, socialists and anarchists: what revolution was that?' in J.A. Piqueras and V.S. Rozalen (eds), A Social History of Spanish Labour: New Perspectives on Class, Politics and Gender, New York: Berghahn Books, 2007, pp241-57.

47. ALBA 243/ 1, p48.

48. Gilroy, Against Race, p233.

49. Gilroy, Against Race; see also G.E. Holcomb, Claude McKay, Code Name Sasha: Queer Black Marxism and the Harlem Renaissance, Gainesville: University Press of Florida, 2007; C.L.R. James, A History of Negro Revolt (1935), London: Race Today Collective, 1985 edn; James, Holding Aloft the Banner of Ethiopia.

50. Editorials by Marcus Garvey in the Black Man in R.A. Hill (ed.), The Marcus Garvey and Universal Negro Improvement Association Papers, Volume VII: November 1927-August 1940, Berkeley: University of California Press, 1990, pp686-95.

51. Editorials by Marcus Garvey in the Black Man, p687. Garvey had initially been enthusiastic about Selassie, but was angered by Selassie's racial politics which were hostile to 'negroes', despite the massive significance Ethiopia had for global black politics. Selassie, for example, shunned a delegation representing the black community in Britain (which included Garvey) when it planned a welcoming reception for him upon his exile to London in 1936: Hill, The Marcus Garvey and Universal Negro Improvement Association Papers, p694, n8.

52. Naison, Communists in Harlem, p138, see also J.E. Harris, African American Reactions to War in Ethiopia, 1936-1941, Baton Rouge: Louisiana State University Press 1994; and W. Scott, Sons of Sheba's Race: African Americans and the Italo-Ethiopian War, 1935-1941, Bloomington: Indiana University Press, 1993.

53. B.G. Plummer, Rising Wind: Black Americans and US Foreign Affairs, 1935-1960, Chapel Hill: University of North Carolina Press, 1996, p42.

54. Harris, African American Reactions to War in Ethiopia, p98.

55. J.W. Ford and H. Gannes, War in Africa: Italian Fascism Prepares to 
Enslave Ethiopia, New York: New York Workers Library, 1935, p3.

56. Naison, Communists in Harlem, pp138-9.

57. Plummer, Rising Wind, p42.

58. See Ford and Gannes, War in Africa; George Padmore, The Life and Struggles of Negro Toilers, London: International Trade Union Committee of Negro Workers, 1931; Naison, Communists in Harlem.

59. Naison, Communists in Harlem, p138.

60. W. Scott, Sons of Sheba's Race, p60.

61. Naison, Communists in Harlem, p156; Kelley, 'This Ain't Ethiopia But It'll Do' in Collum, African Americans, p18.

62. Stuart Hall and C L R James, 'A conversation with C.L.R. James' in G. Farred (ed.), Rethinking C.L.R. James, Oxford: Blackwell, 1996, pp15-44; Chari and Verdery 'Thinking Between the Posts'.

63. Naison, Communists in Harlem, p216.

64. See David Featherstone, 'Black internationalism, subaltern cosmopolitanism and the spatial politics of anti-fascism', Annals of the Association of American Geographers 103, 6, 2013, pp1406-20.

65. Helen Graham, The War and Its Shadow: Spain's Civil War in Europe's Long Twentieth Century, Brighton: Sussex Academic Press, 2012, p82

66. It is likely that Hunter is referring here to the English communist Walter Tapsell. On Tapsell see Richard Baxell, British Volunteers in the Spanish Civil War: The British Battalion in the International Brigades, 1936-1939, London: Routledge, 2004, pp93-5.

67. Oscar Hunter, ALBA 18/3/7 pp30, 36.

68. Ferdinand C. Smith, The NMU Fights Jim Crow, New York: NMU, 1942, p3; see also Gerald Horne, Red Seas: Ferdinand Smith and Black Radical Sailors in the United States and Jamaica, New York, New York University Press, 2005.

69. Interview with Jesse Gray on the National Maritime Union, 6 April 1975, Harry Haywood Papers, Schomburg Center of Research on Black Culture.

70. Proceedings of the National Convention of Maritime Unions, 6-11 May 1946, p186.

71. Graham, The War and Its Shadow, p85.

72. ALBA 143, p25

73. ALBA 143, p20.

74. Haywood, Black Bolshevik, p477; see also Baxell, British Volunteers, p66.

Twentieth Century Communism - Issue 7 
75. See Oscar Hunter, ALBA 18/3/7 p21; Haywood, Black Bolshevik, p489.

76. Salaria Kee O’Neill, ALBA 18/5/8, pp8-9.

77. M. Duberman, Paul Robeson: A Biography, New York: New Press, 1989, pp219-20. The Welsh volunteer Edwin Greening recounts a 'fierce fight' that broke out between 'a group of white Americans and a group of black Cuban International Brigaders in Ripoll prior to the disembarking of the fifteenth brigade, see Greening, E. From Aberdare to Albacete: A Welsh International Brigaders memoirs of his life, Abersychan, Warren and Pell Publishing, 2006, 102.

78. 'Letter from Spain: Addressed to Alabama' in The Collected Poems of Langston Hughes.

79. Luis Girón Echevarriá, 'Langston Hughes's Spanish Civil War verse', Anaurio de Estudios Filológicos, 28, pp91-101.

80. Hugh MacDiarmid, 'An English War-Poet', in Valentine Cunningham (ed.), The Penguin Book of Spanish Civil War Verse, Harmondsworth, Penguin, 1980, pp310-13.

81. Padmore in N. Cunard (ed.), Authors Take Sides on the Spanish War, London: Left Review, 1938, no pagination.

82. George Padmore, Africa and World Peace, London: Secker \& Warburg, 1937.

83. Claude McKay, 'North Africa and the Spanish Civil War' in W. Cooper (ed.), The Passion of Claude McKay: Selected Poetry and Prose 1912-1948, New York: Schocken Books, 1973, pp285-9.

84. A. Smith, 'From subordination to contestation: the rise of labour, 18981918', in Smith (ed.), Red Barcelona: Social Protest and Labour Mobilization in the Twentieth Century, London: Routledge, 2002, p38; P. Trewhela, 'George Padmore: A Critique. Pan Africanism or Marxism', Searchlight, South Africa, 1, 1, 1988, pp42-63.

85. M. Thomas, 'Colonial States as Intelligence States: Security Policing and the Limits of Colonial Rule in France's Muslim Territories', Journal of Security Studies, 28, 6, 2005, pp1033-60.

86. Derrick, Africa's Agitators, p363. This was one of a number of important colonial contexts to the conflict, along with relations with various Latin American countries. For discussions of this aspect of the conflict, see Christopher Schmidt Nowara, 'After "Spain”: A dialogue with Jose M. Fradera on Spanish colonial historiography', in A. Burton (ed.), After the 
Imperial Turn: Thinking with and through the nation, Durham, NC: Duke University Press, 2003 pp157-69.

87. M. Ramnath, Haj to Utopia: How the Ghadar Movement Charted Global Radicalism and Attempted to Overthrow the British Empire, Berkeley, California, 2011, p172

88. Ramnath, Haj to Utopia, p283, n22.

89. A. Heckman, 'Radical (inter-)nationalists: Spanish Civil War, French colonialism and Moroccan Jewish communists', paper presented in the Geographies of Internationalism session, RGS-IBG Conference, 30 August 2013.

90. Adi, Pan-Africanism and Communism, pxx, n27.

91. M. Schmidt and L. van der Walt, Black Flame: The Revolutionary Class Politics of Anarchism and Syndicalism, Edinburgh: AK Press, 2009, p319.

92. Derrick, Africa's Agitators, p363, Trewhela, 'George Padmore', p50.

93. Padmore, Africa and World Peace, p266, n1.

94. Jean Rous, 'Spain 1936-39: the murdered revolution' in Al Richardson (ed.), The Spanish Civil War: the View from the Left, Monmouth, Merlin Press, 1992, p385.

95. S. Balfour, Deadly Embrace: Morocco and the Road to the Spanish Civil War, Oxford, Oxford University Press, 2002, p. x.

96. 'David Rousset's Testimony' in Miguel Romero, The Spanish Civil War in Euzkadi and Catalonia, Notebooks for Study and Research, no.13, Amsterdam, 1991, pp41-3.

97. Rous, 'Spain 1936-39', p401, n52.

98. ALBA 243/ 1, p73.

99. Makalani, in The Cause of Freedom, p124.

100. ALBA 243/ 1, p73.

101. ALBA 243/ 1, p88.

102. On Bailey see B. Nelson, Workers on the Waterfront: Seamen, Longshoremen and Unionism in the 1930s, Chicago: University of Illinois Press, 1988, pp89, 90, 95-6.

103. Bailey, ALBA 18/1/2, p175.

104. McKay, A Long Way From Home: An Autobiography (1935), London: Pluto Press, 1985 edn, p75, Makalani, In the Cause of Freedom, p87.

105. Makalani, In the Cause of Freedom, p73.

106. Earl Browder, The People's Front, New York: International Publishers, 1938.

Twentieth Century Communism - Issue 7 